\title{
Research Summary \\ Information and Communication Technologies and Poverty: The Telecentre Movement in Java
}

\author{
Widjajanti M Santoso \\ Research Centre for Society and Culture \\ Indonesian Institute of Sciences
}

This article discusses telecentre development in Indonesia but focuses on case studies of telecentres in Java. The research uses twelve indicators from Rao (UNCTAD, 2006: 186) to help illustrate telecentre development. This research, which uses qualitative methods (structured interviews), is to help shape national policies that will enable communities to prosper by benefiting from information and communication technology for poverty reduction (ICT4P). It draws on the research and experience of using ICT4P internationally, nationally and in other parts of Indonesia. ICT4P is partly a global commitment by many nations, under the auspices of the United Nations, that gathered together at the World Summit on the Information Society (WSIS) in Switzerland in 2003 and in Tunis in 2005. The global commitment is to understand the different interests between poor, third-world countries and others. Therefore, in their points of agreement, promoting information and communication technology (ICT) was one of the commitments, and Indonesia has stated its target is to have 50 per cent of its people with internet connectivity by 2015 . The reaction to this program varies; Jatim Province is very positive that it will now build

1 This research has been made possible by the Critical and Strategic Social Issues (CSSI) program in LIPI. The team comprises Widjajanti M Santoso as coordinator and Nina Widyawati, Katubi, Djoko Waluyo and Rochmawati as researchers. 
telecentres using the UNDP-Bappenas design but will fund them from its own provincial and municipal budgets. ${ }^{2}$ Other provinces did not give it much attention, but there are other civil society initiatives to build different types of telecentres suitable for local needs.

The results are several, but the main argument for building telecentres lies in a telecentre's bifurcated position as an institution for empowering citizens but also as an income generator, because they have to be self-sufficient. To do this, a telecentre needs, first, not only a person capable of meeting the demands of both requirements but also to have full-time staff. A telecentre is not easily able to survive by itself and generally would not be able to generate income enough to enable it to pay its staff a sufficient salary. Second, there is little synergy among institutions to support the telecentres and vice versa. As an example, provincial trade and industry offices are hard-pressed to support the e-business needs of the small industries based in rural areas. Third, most members of local society understand the potential of telecentres but are unable to adapt them to their economic activities. They depend on the telecentre for access to information and for it or its staff to interpret that information for them. Fourth, either the telecentre staff or the local society needs to have basic knowledge of e-management and e-business to support their economic activities. Some telecentre clients are able to upload information about their small-scale business product but have problems supplying the industrial demand. Last, there is a gap of perception between the staff and the rest of the society on the function of telecentres in rural areas. Local people see telecentres as institutions that can support the community by distributing (and receiving) information, by enabling access to finance when needed and by contributing to education and training needs. In reality, although the staff usually are more knowledgeable than the users, they need to be supported to improve their skills and knowledge to help and to satisfy their users' needs.

2 Bappenas is the portmanteau abbreviation for Badan Perencanaan Pembangunan Nasional (National Development Planning Agency, Republic of Indonesia). 


\section{Poverty reduction and electronic communication}

Information and Communication Technologies for Poverty Reduction (ICT4P) is a poverty reduction program for people or communities that lack access to computers and the internet, such as remote and rural villages. To be more specific, ICT4P is not necessarily for rural areas but for poor or marginalised communities anywhere. The general mechanism to enable such computer and internet use is by using a community access point (CAP), and telecentres are one such mechanism. The Partnership for the e-Prosperity for the Poor (PePP) is a program implemented by UNDP-Bappenas cooperation as a pilot project in Indonesia. This program is part of a commitment made by countries through a global awareness strategy at the World Summit on the Information Society (WSIS). The Summit itself involved several meetings in Geneva in 2003 and in Tunis in 2005, and one result was the commitment, called the Geneva Declaration Principle, to understand the need to build the information society. Not only that, the commitment also took into account the different situations and challenges of thirdworld countries that have a specific focus on reducing povert .

We are resolute to empower the poor, particularly those living in remote, rural and marginalized urban areas, to access information and to use ICTs as a tool to support their effort to lift themselves out of poverty. (Depkominfo, 2006: 19)

Nationally, Indonesia has several important handicaps to the implementation of ICT: in the Networked Readiness Index 2012, Indonesia is ranked 80 of 142 countries; in computer use it is 29 out of 44 countries; and in ICT development, using the UNCTAD-UNDP index, it is 77 of 171 countries. According to UNDP-Bappenas, in 2004, the ICT infrastructure could provide for 1 to 5 per cent only of Indonesia's population of approximately 250 million. But apart from that drawback, Indonesia has a program, titled 201550, which is to be 
read to mean that by 2015,50 per cent of Indonesia's population will be able to connect to the internet.

In a national context, Indonesia acknowledges the problem of limited access to ICT and this explains the low use of ICT.

Kesenjangan digital disebabkan oleh (a) terbatasnya daya beli (ability to pay) masyarakat terhadap sarana dan prasarana pos dan telematika; (b) masih rendahnya kemampuan masyarakat untuk memanfaatkan dan mengembangkan teknologi informasi dan komunikasi; dan (c) terbatasnya kemampuan masyarakat untuk mengolah informasi menjadi peluang ekonomi, yaitu menjadikan sesuatu mempunyai nilai tambah ekonomi. ${ }^{3}$

[Digital divides are caused when (a) communities have limited resources to afford access to, and the facilities of, ICT; (b) communities have insufficient capability to use and to develop ICT; and (c) communities have limited capacity to access economic information and, therefore, to use it to add value.]

Indonesia has said that the development of ilmu pengetahuan dan teknologi (IPTEK) or science and technology should pay particular attention to ICT.

Pembangunan iptek diarahkan untuk mendukung ketahanan pangan dan energi; penciptaan dan pemanfaatan teknologi informasi dan komunikasi ${ }^{4}$ [The development of knowledge and technology are to support food and energy security, and to support the creativity and benefits of IC .]

For poverty eradication, Indonesia, through Bappenas, has produced the TIK: Strategi Peduli Kemiskinan. In this document, ICT is seen as a tool to help eradicate poverty.

3 Indonesian law 17 of 2007. [Undang-undang Republik Indonesia nomor 17 tahun 2007 tentang rencana pembangunan jangka panjang nasional tahun 2005-2025.]

4 This text is taken from presidential decree 5 of 2010, section 4.3.1, and was accessed on 22 August 2012 at http://www.ristek.go.id/file/upload/Referensi/2010/rpjm_bapenas/buku-ii-bab-i .pdf. 
TIK [strategi teknologi, informasi dan komunikasi] sebagai alat bantu dalam upaya mengurangi kemiskinan, bukan sebagai hasil penanggulangan kemiskinan. (Bappenas, 2006: 2)

[ICT is one way to help the efforts to lessen poverty, but the result will not be the prevention of poverty.]

The document states that the ways to implement ICT for the people, and for the poor especially, are

. . membina hubungan erat dengan pemuka masyarakat lokal di pemerintahan dan swasta untuk membantu mereka membentuk kemitraan dalam penggunaan TIK yang diwujudkan dalam bentuk telecentre. (Bappenas, 2006: 24)

[... to have close relations with local leaders in government and private institutions, to support partnerships with them, and to use telecentres as the model for ICT.]

Therefore, the telecentre is an important means to enable people to know and to fulfil their potential. In this respect, a telecentre is not only a different type of community access point (CAP) but the telecentre itself may be thought of as suitable for eradicating poverty.

Other research is being done (Wisnu, 2008) as part of the telecentre implementation program and this research shows that the community around the telecentre, especially the younger generation, uses the telecentre's internet access and other facilities. But still a custom-made approach is important to cater for specific occupations and interests in any one community. Most telecentres have spare time at night; therefore, they need to open until late. One of the recommendations of this research is that there be more development of telecentres. The province of Jatim and the telecentres formed the Asosiasi Telecenter Jawa Timur, and they work together with Dinas Komunikasi dan Informasi (Diskominfo). The province of Jatim also has researched the development of telecentres with the UNDP-Bappenas initiatives in 
mind but also it has its own distinct needs for telecentres in the regional areas of the province (Aptel, 2009). ${ }^{5}$

This monitoring and evaluation shows that most users are from the younger generation, and that most of the telecentres in Jawa Timur Province are able to maintain continuity, although with difficult . But the most difficult to be implemented in the telecentre is to produce the infomobilisation. Some telecentres have financial difficulties because they need to pay for connectivity, for maintenance of equipment and for 'salaries' of their staff. Communities are accepting of the telecentres but the program has not yet shown itself to be successful.

Having said that, under the scheme of poverty policy research, this article describes the implementation of telecentres in Indonesia. For this year, the cases are from Java. The team has visited the telecentres in Lumajang, Muneng and Pabelan and used snowball sampling techniques and guided interviews to gather data. Not only that, but the team has also visited other types of community access points (CAP) to get a better picture of civil society initiatives in this kind of program. The team hopes it will be able to describe the ICTs for the people's development in Indonesia. The team uses the twelve Rao indicators to standardise the descriptions of the circumstances and challenges of the telecentres and other CAPs (UNCTAD, 2006: 186). The team wants to show the general situation of the telecentres and other CAPs and the successes of the program. By putting the scheme in global, national and local contexts, this research intends to show its significance not only on policy abut also on its implementation and on Indonesia's position in ICT development.

\section{Program implementation}

In Indonesia, the UNDP-Bappenas cooperation has pioneered a telecentre program, called Partnership for e-Prosperity for the

5 Asosiasi Telecenter Jawa Timur, Dinas Kominfo dan Informatika Propinsi Jawa Timur, Laporan Akhir Monitoring dan Evaluasi Kinerja Telecenter Jawa Timur 2009. 
Poor (PePP). To meet the specific requirements of the program, the organisation of a telecentre is complex and needs one or more staff to be manager, infomobiliser, operator, and IT administrator. The building that is used for a telecentre also has specific requirements; it needs to have an IT room, a multimedia room and meeting rooms. A telecentre is best sited in a poor community, that is, one that has at least 30 per cent of its people considered to be poor but an essential prerequisite is a reliable electricity supply. The program must also provide the telecentre's management with knowledge of what the purpose of a telecentre is and how it should be run. In reality, as the experience of the first telecentre in the Pabelan Pesantren (an Islamic school) shows, the PePP program managers and the neighbouring community need to cooperate to ensure the growth of the telecentre and that it meets local needs.

Table 1 depicts the twelve indicators of Rao that have been used as the baseline for gathering information from informants. The Rao indicators show not only the organisational needs but also the social situation of the telecentre's neighbourhood and the problems and challenges for the telecentre.

Table 1

Twelve indicators of ICT and poverty reduction program

\begin{tabular}{|l|l|}
\hline Indicators & The issues \\
\hline Connectivity & $\begin{array}{l}\text { Connectivity is to do with ICT infrastructure and access and also } \\
\text { its price. } \\
\text { The question of connectivity is for telecentre management, local } \\
\text { and national government and infomobiliser. }\end{array}$ \\
\hline Content & $\begin{array}{l}\text { Content is showing whether the information available is } \\
\text { compatible with and accessible to the targeted group. } \\
\text { The question of content are for infomobilisers, management, local } \\
\text { organisations, and group members. }\end{array}$ \\
\hline
\end{tabular}




\begin{tabular}{|c|c|}
\hline Indicators & The issues \\
\hline Community & $\begin{array}{l}\text { Who benefits and whether the ta geted group is able to } \\
\text { negotiate the program. } \\
\text { The questions are for management, infomobiliser, local and } \\
\text { national government and members of the target group. }\end{array}$ \\
\hline Commerce & $\begin{array}{l}\text { Seeking the potential of productive activity especially in business. } \\
\text { The questions are for management, infomobiliser and members of } \\
\text { targeted group. }\end{array}$ \\
\hline Capacity & $\begin{array}{l}\text { Seeking the capacity of the targeted group, telecentre organisation, } \\
\text { and society to deal with the new demands. } \\
\text { Questions are for management, local government and members. }\end{array}$ \\
\hline Culture & $\begin{array}{l}\text { Seeking the interaction with current culture and promotion of ICT } \\
\text { education. } \\
\text { Questions are for management, local government and } \\
\text { infomobiliser. }\end{array}$ \\
\hline Cooperation & $\begin{array}{l}\text { Cooperation between different stakeholders. } \\
\text { Questions are for management and government. }\end{array}$ \\
\hline Capital & $\begin{array}{l}\text { Seeking financial viability. } \\
\text { Questions are for local government, management and } \\
\text { infomobiliser. }\end{array}$ \\
\hline Context & $\begin{array}{l}\text { How to adapt to local contexts and interests. } \\
\text { Questions are for management, local government and group } \\
\text { members. }\end{array}$ \\
\hline Continuity & $\begin{array}{l}\text { Seeking the mechanism of evaluation, flexibility and potential } \\
\text { development. Questions are for management, local government } \\
\text { and infomobiliser. }\end{array}$ \\
\hline Control & $\begin{array}{l}\text { Seeking the ownership of the telecentre and accountability of the } \\
\text { stakeholders. } \\
\text { Questions are for management, local government and } \\
\text { infomobiliser. }\end{array}$ \\
\hline Coherency & $\begin{array}{l}\text { Seeing the program' s implementation and its position with } \\
\text { regard to poverty. } \\
\text { Questions are for government, Ministry of Communication and } \\
\text { Information, and observers. }\end{array}$ \\
\hline
\end{tabular}

Table 2 shows the social environment of telecentres and CAPs. From this table it can be seen that telecentres that have a blueprint of planning for 
poverty are quite ready to face the necessity to survive. The telecentre planning has given them some workshops and training to enable the managers to run the centres and to cater for community's needs. Therefore the management is trying very hard to ensure the telecentres sustainability. The number of people who work in the telecentre has been reduced since the program finished several years ago. The people who are still in the telecentre are people who are committed and accept the social situation. They have passion and spirit to make the telecentre live.

Table 2

Problems and challenges of telecentres and other CAPs

\begin{tabular}{|l|l|l|}
\hline Indicators & Telecentre & Other CAPs \\
\hline Connectivity & With difficulty. & $\begin{array}{l}\text { According to the situation and } \\
\text { dependent on the host. }\end{array}$ \\
\hline Content & $\begin{array}{l}\text { Community' s goods and } \\
\text { services, and activities. }\end{array}$ & $\begin{array}{l}\text { Not accessible, only a few } \\
\text { telecentres upload their information. }\end{array}$ \\
\hline Community & $\begin{array}{l}\text { Cater for community and } \\
\text { search rational mechanism. }\end{array}$ & $\begin{array}{l}\text { Cater for specific communities, } \\
\text { such as groups or people in the } \\
\text { surrounding area. }\end{array}$ \\
\hline Commerce & Only a few users. & Not accessible. \\
\hline Capacity & $\begin{array}{l}\text { The management is also } \\
\text { building or upgrading the } \\
\text { capacity. }\end{array}$ & Not catered for. \\
\hline Culture & Not accessible. & Not accessible. \\
\hline Cooperation & $\begin{array}{l}\text { Depending on the process of } \\
\text { implementation. }\end{array}$ & $\begin{array}{l}\text { Limited coordination, the emphasis } \\
\text { is on their independence. }\end{array}$ \\
\hline Capital & With difficulty. & With difficulty. \\
\hline Contexts & Not yet. & Not yet. \\
\hline Continuity & With difficulty. & $\begin{array}{l}\text { According to the situation and } \\
\text { mostly are new. }\end{array}$ \\
\hline
\end{tabular}




\begin{tabular}{|l|l|l|}
\hline Indicators & Telecentre & Other CAPs \\
\hline Control & $\begin{array}{l}\text { The management and } \\
\text { stakeholders are not always } \\
\text { in line with each other. }\end{array}$ & Not clear. \\
\hline Coherency & $\begin{array}{l}\text { The management are } \\
\text { conscious of it. }\end{array}$ & Not catering for poverty. \\
\hline
\end{tabular}

In fact, the process when a telecentre is first set up is very important for its survival, especially in minimising any resistance or hesitation from the community and other stakeholders. The process in East Java province has been very good because the provincial government is seen as a joint partner in the program. Therefore, instead of only one telecentre, the Smeru telecentre in Lumajang, East Java Province has two with the addition of the Muneng telecentre in Madiun. All the telecentres are still in operation, although they have had to reduce their services, especially the infomobilisation that formerly had been paid for by the UNDP-Bappenas program. Infomobilisation is responsible for the empowerment program within the community, and infomobilisers are knowledgeable persons and able to motivate people and to coordinate activities. The telecentre has to rationalise by reducing the number of staff who work there. To maintain the computers, they might have to cannibalise other computers because there are not funds enough to fix or rejuvenate or upgrade those they have. The telecentre is now accepting money from the community, but it is only enough to pay the monthly overheads, such as electricity and phone bills.

The community has already benefited from the telecentre. It has provided them with a facility to acquire information from beyond their community. The telecentre has also made it easy for the people to get digital photos printed: formerly, they would have had to go to a nearby town to a photo-developing service. Some small-scale agricultural enterprises have been enabled to take orders over the internet but they have problems meeting standards of quality and productivity volumes. It is a new experience for them. Some farmers have multiplied agriculture 
profits by using information from the internet; others have been able to anticipate market prices by monitoring and anticipating supply and demand. Most of the managers of the telecentres point out that the most achieved goal is being able to educate the dropouts and peasant workers to be able to use and operate equipment at the telecentres. The managers have taken it upon themselves to provide infomobilisation services, that is, they have instructed people in how to use computers and to suggest apt terms to use for internet searches. Many of the telecentre users who need such help are those with a good education, school teachers, for example.

Not everyone agrees that the telecentres are wholly beneficial; allowing the peasant community to use computers and the internet runs against social traditions, and then there is the matter of the costs to the community of the telecentres. The use of computers and the internet is influenced by social class and it is not believed to be the prerogative of the common people: the middle and upper classes are felt to be the prime users of both, not to mention other communication technology, such as the mobile phone. For others, computers and the internet tend to be seen as bad influences because information is more easily obtainable, including pornography. Computers and the internet are also seen as a means for wealthy countries to bring their influence to bear on rural people and agricultural communities, which are usually beyond their ken.

\section{Poverty and the Internet}

The connection of CIT and poverty eradication is not at first sight obvious because there is a general assumption that computers and the internet are the preserve of the educated, urban middle classes. But promoting the internet's benefits for the poor is about the general right to economic and social development because people, whoever they are, have a right to develop to their full potential. Therefore, in this case, the 
context is state intervention in using the internet as a development tool for most of the people, including those in rural and remote areas.

The other significant mat er when discussing this relation of IT and poverty eradication is the use of the term 'poverty'. There are several meanings of poverty; for example, Sachs (2005 has three meanings. First, is extreme or absolute poverty; second, is moderate poverty and the third is relative poverty. People in extreme poverty live in desperation to meet their basic needs, have no access to health, education, housing, nor to decent clothes. Moderate poverty means that people can meet their basic needs. Relative poverty applies to people whose salaries are under the average of the general income, have limited access to education and other needs that are important for them to raise their living standards.

According to the United Nations Conference on Trade and Development (UNCTD), there are three aspects to poverty. First, 'monetary poverty' applies to people whose income is below the poverty line; second, 'capability poverty', where people have limited access to substantive freedoms, such as health, education, political expression and more; and third, social exclusion, which applies to people who have limited ability to participate in society. This technical definition of poverty categorises people according to the situational disadvantage that prevents their full participation in society and hinders their social mobility. In this categorisation of poverty there are two ways to alleviate the condition; the first is to improve the social situation, which would enable absolute poverty to be minimised. The second is to give to the poor ways of enabling social mobility. This second path to poverty alleviation is trying to narrow the gap by redistributing social goods and reducing inequality.

Because there are many poverty definitions, this article focuses on the concept of relative poverty to give specific context to how the internet and might lead to poverty eradication. The definition of poverty is very important, especially in a third-world context, where 'poverty' is generally understood to mean absolute poverty. In the third world, the poor are ever present and their condition is one of absolute poverty. A 
theme of this article would be that the implications of relative poverty tend to be put aside because those people in the communities that are in relative poverty do not meet the popular understanding of poverty. Most people would not see the concept or definition of relative poverty as important. What is bothersome in using the concept of relative (or group) poverty is that it is up against the common understanding that poverty affects individuals: to consider a group or community as a unit of poverty requires a little rethinking. In terms of absolute poverty, this individual indexing of the poor could be useful, but in using the idea of relative poverty there is some confusion in the community. Social policies based on the concept of relative poverty imply that intervention should be aimed at a community or a society as are the ICT4P programs. Telecentres cater for the poor in relative terms and tackle poverty as a community matter rather than dealing with it individually. Where there is poverty, most of the surrounding area will be still close to poverty, therefore the community or the society itself is poor in relative terms.

In Indonesia, poverty is becoming the political debate as can be seen from the discussion of poverty during political campaigns. The Partai Demokrasi Indonesia Perjuangan (PDIP) has long used 'the poor' or wong cilik (common people as a specific term to identify its closeness to the situation. The Partai Demokrasi, the ruling party at present, is using bantuan langsung tunai (BLT) or direct help with cash as a part of its political identification. The solutions to the problem of poverty have been described using three important metaphors. The first metaphor sees the solution to poverty as one of giving fish to the poor, such as BLT; the second is giving the poor a fishing net to enable them to be independent; and the third is giving them a boat so that they can rise above the poverty line, perhaps even creating jobs for other people. In reality, dealing with absolute poverty is the more politically acceptable way of being seen to be eradicating poverty. Therefore, absolute poverty is becoming an accepted political commodification and, in the process, the matter of relative poverty is being left out of the discussion. 
But how the internet is to help with the poverty problem is still under discussion. Martin Franklin (2006) uses McNamara's (1973) argument to show how ICT relates to poverty eradication programs in three ways. First, ICT is seen as tool to empower the poor; second, ICT must be given priority to support investment and development in selected areas; and, third, ICT is a way to change the mind-sets of the community, of political leaders and of the bureaucracy so they might see it as enabling a prime environment for productivity increases. Arguments such as these are compatible with the issue that development is a community right. In this sense, ICT is a development right, therefore it is a public facility that should be provided for.

The third point in the previous paragraph emphasises the need to change mind-sets because most people understand ICT to be for middle and upper classes, which are mostly urban. Therefore, to some extent, there is the need to change the mind-set so that ICT infrastructure is seen as a natural or necessary part of development, even in the remotest areas. If poverty and its eradication or its amelioration is tackled as a matter of relative poverty then this strengthens the case for ICT at village level. Relative poverty tends to show the poverty of the community rather than the poverty of the individuals in that community. In this sense, even if an individual is not poor but his environment is poor, then there is a need for investment in ICT. In reality, better educated individuals or with more experience because of his or her mobility would fit the ICT requirement. But in reality people in remote areas and in remote villages have limited possibilities to any development that ICT could support.

To view ICT as networks of infrastructure and public facilities is to see it as a part of development rights. These rights are a part of the Universal Declaration of Human Rights, and have been emphasised throughout the 34th United Nations Conference on Environment and Development (UNCED) in 1992. One important point agreed at that conference is that ICT is a part of sustainable development in developing countries. Therefore, government has a responsibility to provide ICT infrastructure 
to poor, marginalised people and to those who live in the remoter areas of the country.

The ideas and assumptions of society as a whole are playing an increasing part in social theory and for the poor and underprivileged to participate it is necessary that ICT be easily available. According to Manuel Castells (2000), more and more the world is reshaping as the networked society in which computers and the internet play important roles. In the networked society, more and more, economic development would be improved or retarded by the use or not of computers and the internet. Therefore a person, people, or a community that has limited access to either or both would need to put a greater effort into eradicating their poverty. The poor are marginalised in accessing knowledge and information. Therefore, poverty in the sense of relative poverty could be eradicated on the assumption that giving them access to information and information networks would enable them to avoid the poverty trap.

In terms of the networked society scheme of things, the poor are part of a global situation, to be poor is to be part of the poverty network. This perspective moves the identification of the poor from the individual to the social situation of the poor. Therefore, poverty should be seen in a wider context, such as the community or society. The networked society also makes the claim that computers and the internet play important roles in terms of access to information that can help to fight povert . To follow this line of thinking, Indonesia should put more thought into understanding the significance of the computers and the internet

As has been shown before, to understand the importance of computers and the internet, there needs to be a shifting of the mind-set. It is also has been shown that it is not easy to change mind-sets, let alone change the behaviour and attitudes to computers and the internet. The general acceptance and approval of ICT by the poor is hampered by the idea that computers and the internet will lead to moral degeneration, especially of the younger generation, and that ICT is for the use and benefit of educated, urban middle and upper classes. It is also thought that those 
in remote areas, in isolated villages and who belong to the lower orders, are unsuited to programs that encourage the use of ICT.

In Castells' view (1996) the space of flows is about the sequences and interactions between actors and institutions whose behaviour, strategy and policy shape spacial outcomes (Southern, 2001: 427).

If Castells' arguments are to be accepted, there is a need for countries who want to break the poverty trap to change mind-sets as well as build the infrastructure of ICT. According to Castells, to get a specific outcome using the ICT there needs to be an accepting mind-set and infrastructure support by farsighted government policies because this is a sociological structure that would push forward the changing of behaviour. This is not easy because it is a part of the digital divide in countries such as Indonesia.

The contribution ICT can make is as a tool that can enable communities, and countries, to escape the poverty trap. But ICT is not only about the people but also the technology and vice versa. It is a part of the challenge for people who want to eradicate poverty to include ICT in their scheme.

It is much more than mere use of technology. It is more a question of working with people, giving them a sense of ownership, building partnerships with a number of experts and institutions, and creating a large and inclusive network. In the end, technology is just an enabler (Weigel and Waldburger, 2004: 215).

Weigel and Waldburger (2004: 206-227) advocate that people, in this case the Indonesian people, should be encouraged to the view that computers and access to the internet are social and economic goods that need support and sufficient funding because they are a necessary element of infrastructure. The PePP pilot project has shown the way and should be seen as a positive step not an aberration. The arguments by 
those who decry the benefits from enabling computer use and internet access need to be countered by changing the common perceptions of poverty and showing how it might be mitigated by the benefits of ICT that have resulted from globalisation

\section{Conclusion}

The biggest challenge for the telecentres is their position between their function to empower the community and to cater for business needs. The empowerment is a function of the infomobilisation. Telecentres are not able to hire infomobilisation staff because of the high salaries needed, which the PePP formerly paid. The province of Jawa Timur understands the importance of infomobilisation and on their own initiative they are developing telecentres in every municipality. They understand their financial limits and therefore they have rationalised telecentre management to three important roles and functions only; management (with a capacity for infomobilisation), secretarial and operational. They maintain equipment by outsourcing, by depending on local computer repair shops or by relying on a staff member with the right skills.

But for people who believe that technology is able to distribute information far more widely and that it is an essential element of the social and commercial infrastructure for people and communities on the margins of society, this program is very important indeed. This is evidence that ICT delivers benefits. The challenge is to overcome the perception that people in remote and rural areas are incapable of using or benefiting from new technology and techniques

The PePP is in East Java Province, which, considering the geographical extent of the Indonesian archipelago, can not be considered a remote area, but the lessons learnt and the technological possibilities exposed can be applied anywhere. The people behind the bureaucracy of this province already are able to understand the basic principles of this program, and these have to be followed by the other provinces. 
Using ICT for poverty reduction should be one of the main programs to facilitate regional autonomy but political interests tend to dominate development programs. Discussion of regional autonomy and development includes social development for all classes of society, which in turn will lead to growth in productivity and employment. Enabling the economic growth of rural areas is a part of the networked society's predicament of development.

It is not easy for this program of establishing telecentres to be understood because it can be stereotyped as a rolling out of ICT, as a program to distribute modern communication technology only. For some observers, the program is a part of a neoliberal agenda to suck resources from third-world countries, a point of view that gets added credence from the known effects of the global economy. As has been shown, ICT is part of a global commitment by countries, under the United Nations, that understand the neoliberal pro and con arguments. Therefore, the commitment to counter poverty needs to be understood in terms of a network, otherwise people would protest about negative effects on third-world countries. There is a need to have an alternative to eradicating the poverty using ICT. Not to have such a strategy would put third-world countries further behind.

To some, ICT is a tool, an enabler, and it means that ICT is an important element of infrastructure. For ICT to have an effect on the eradication of poverty, it is necessary for a nation to include ICT in its infrastructure, for poverty is not an individual problem and a nation should have special strategies to fight it, in this case, to bridge the digital divide. In this line of thinking, the nation should invest in ICT infrastructure. ICT as infrastructure is also a part of development rights; therefore, a nation should provide ICT for poor, marginalised people and people in the remote areas.

The telecentres in this study have had some influence, direct and indirect. The direct influences are that the telecentre provides information on market prices, employment and other pertinent topics. The telecentres give opportunities for people to develop ICT and related skills; therefore, 
there is a trickle-down effect for some people that will enable them to raise their incomes. The program needs an appropriate evaluation to view the problem in terms of digital divide indicators. This is important because the PePP program suffers from a perception that poor people are incapable of using computers and the internet. The program itself needs a longer implementation time because it should set up a solid foundation for a system of knowledge and infrastructure. In terms of poverty, the persistence of relative poverty has shown that poverty is not easy to fight and the program can not show a direct welfare effect. Some people used to see the implications of poverty as linear and that programs to eliminate it would add to the welfare of society. But in reality, poverty is mostly quite difficult to see

As a program, it is important that ICT4P be included in government development of electronic means for economic and welfare ends. The government needs to include this program in its blueprint as a part of its commitment to the global awareness of co-opting ICT for development. ICT has made it possible for people to get information about the global demand for commodities that could be used to find and develop products for markets. But to do this, according to the experience of the PePP program, the role of infomobiliser is very important. It is quite expensive to have a specific person assigned to the role but there are several persons able to be educated for the role, such as computer operators. People in rural areas still need a person to interpret the information they need to download from the internet.

Indonesia has a grand plan for ICT implementation in its remote areas. But this grand plan might not come to much more than a long running, jargon-filled discourse instead of realising its purpose; that is, to meet the needs of society. This study is showing that people who live in rural areas at present are badly in need of other, more effective methods to enable better agricultural production. ICT, as a readily available tool, can be used to enable quicker and more certain ways to communicate to Indonesian workers about the social and legal arrangements in other countries to where they hope to emigrate. Many migrant workers have 
no idea of the social situation in the countries they intend to work in. For example, ICT can help to record and to broadcast the experiences of migrant workers who have worked in foreign countries. Not only that, publicly available technology will allow cheaper and faster communication with relatives.

For the community, there is a need for internet literacy to be provided by the telecentres and educational institutions. Such literacy is needed to enable, and to protect, the people who use the new technology. ICT is a mode of communication that is quite different from what people have used previously. That computer and communication literacy is necessary to enable would-be users is to state the obvious; but is it also necessary for their protection? Yes, because computer skills and knowledge can be used for criminal purposes against naïve, complacent or ignorant users and, as well, there are privacy concerns about personal statements and the uploading of photographs.

To understand the logic of ICT use, it is important to know and understand how streams of information now extend worldwide and that connectivity is very important for those people and communities who need to tap into these streams. The network perspective used in this article has shown that poverty, relative poverty that is, will not change if access to computers and the internet is limited or not available. In this situation, people or communities that don't have access to ICT suffer more poverty than do those people or countries in which governments have enabled such access. Telecentres are different from internet cafés; they help to raise a community's level of ICT skill and knowledge, to empower it; internet cafés are for those individuals who are already skilled. There is so much to be done to provide better access to ICT with programs such as the CSR (corporate social responsibility) scheme. It only a part of the synergy among the constituents of the social situations in each community. 


\section{Bibliography}

Asosiasi Telecenter Jawa Timur, Dinas Kominfo dan Informatika Propinsi Jawa Timur, Laporan Akhir Monitoring dan Evaluasi Kinerja Telecenter Jawa Timur 2009

Bappenas. (2006). Teknologi, informasi dan komunikasi: strategi peduli kemiskinan. Jakarta: Bappenas.

Castells, Manuel. (2000). The rise of the network society. 2nd edn. Oxford: Blackwell.

Depkominfo. (2006). Dokumen hasil Sidang Konferensi Tingkat Tinggi Dunia Mengenai Masyarakat Informasi Geneva 2003 - Tunis 2005. Jakarta: Departemen Komunikasi dan Informatika.

Franklin, Martin. (2006). 'Suggested best practice for pursuing development and poverty reduction through national strategies'. Journal of East Caribbean studies, 31(4).

McNamara, RS. (1973). Address to the Board of Governors [the 'Nairobi Speech']. Washington: International Bank for Reconstruction and Development.

Sachs, Jeffrey. (2005). The end of poverty: how we can make it happen in our lifetime. London: Penguin Books.

Southern, Alan. (2001). 'How where why and when information technologies are seen as a regeneration policy'. International journal of public sector management, 14(4/5): 427. Accessed 9 August 2009 from http/www.emerald-library.com/ft.

UNCTAD. (2006). Information economy report 2006: the development perspective. Geneva: United Nations Conference on Trade and Development.

UNCTAD. (2003). Information and communication technology (ICT) development indices. Geneva: United Nations Conference on Trade and Development.

Weigel, Gerolf and Daniele Waldburger (eds). (2004). ICT4D-connecting people for a better world: lessons, innovations and perspectives of information technologies in development. Berne: Swiss Agency for Development and Cooperation (SDC), Global Knowledge Partnership (GKP).

Wisnu, Taru J. (2008). 'Riset aktivitas dan keberlanjutan telecentre Pe-PP'. (unpublished). Jakarta: Bappenas-UNDP. http://www.nationmaster.com/ graph/med per com percap-media-personal-computers-per-capita, accessed 30 July 2012. 